\title{
MODEL PEMBINAAN PENDIDIK DI PONDOK PESANTREN NURUL HAKIM LOMBAK BARAT
}

\author{
Abd. Muin M
}

\begin{abstract}
This research is aimed at studying the model of development for teachers at Pondok Pesantren (Islamic Boarding School). The research was conducted at Pondok Pesantren Nurul Hakim Lombok where thousands of young generations of Moslems have been studying Islamic knowledge and science. The research used qualitative method with interview as main tool of data collection. The research found that Pondok Pesantren Nurul Hakim where Kyai (Moslem intellectual) is regarded as a model of education is one of the biggest pesantren in Lombok. The research also found that most of the teachers were graduates of universities and teacbing subject in line with their educational background.
\end{abstract}

Keywords: model, generation, teachers, universities, educational background

Drs. H. Abdul Muin M.Pd adalah Peneliti pada Puslitbang Pendidikan Agama dan Keagamaan, Badan Litbang dan Diklat Departemen Agama RI

\section{PENDAHULUAN}

Dalam tradisi pesantren, pendidik berada dalam otoritas kyai. Kyai merupakan elemen yang paling esensial dari suatu pondok pesantren. Kyai merupakan sumber mutlak dari kekuasaan dan kewenangan dalam kehidupan dan lingkungan pondok pesantren. ${ }^{1}$ Selain itu, kyai merupakan yang tertinggi dari hirarki kekuasaan

1 Zamakhsyari Dhofier. 1982. Tradisi Pesantren: Studi tentang Pandangan Hidup Kyai. Jakarta: LP3ES, h. 55. 
intern di pondok pesantren dan memiliki kedudukan ganda sebagai pengasuh dan sekaligus pemilik pondok pesantren. ${ }^{2}$

Sejak disahkan Undang-Undang RI Nomor 20 Tahun 2003 tentang Sistem Pendidikan Nasional, secara yuridis keberadaan pesantren telah diakui, dan lebih diperkuat lagi setelah lahir Peraturan Pemerinah RI Nomor 55 Tahun 2007 tentang Pendidikan Agama dan Pendidikan Keagamaan. Dengan demikian, ketika pondok pesantren melakukan adaptasi terhadap sistem di luar pondok pesantren maka otomatis pendidik di pondok pesantren harus sesuai dengan tuntutan undangundang dan peraturan yang berlaku. Ini berarti, pondok pesantren dihadapkan pada perlunya penyesuaian dengan perubahan dari luar, yaitu dengan Undang-Undang RI Nomor 14 Tahun 2005 tentang Guru dan Dosen dan Peraturan Pemerintah RI Nomor 19 Tahun 2005 tentang Standar Nasional Pendidikan serta Peraturan Pemerintah RI Nomor 74 Tahun 2008 tentang Guru. Undang-Undang RI Nomor 14 Tahun 2005 Pasal 8 menyebutkan bahwa guru wajib memiliki kualifikasi akademik, kompetensi, sertifikat pendidik, sehat jasmani dan rohani, serta memiliki kemampuan untuk mewujudkan tujuan pendidikan nasional. Pada Pasal 9 ditegaskan bahwa kualifikasi akademik dalam Pasal 8 diperoleh melalui pendidikan tinggi program sarjana atau program diploma empat. Selanjutnya pada Pasal 10 ayat (1) juga ditegaskan, bahwa kompetensi guru sebagaimana dimaksud dalam Pasal 8 meliputi: kompetensi pedagogik, kompetensi kepribadian, kompetensi sosial, dan kompetensi profesional yang diperoleh melalui pendidikan profesi.

Begitupun dalam Peraturan Pemerintah Nomor 19 Tahun 2005 pada Pasal 28 ayat (1) diperjelas, bahwa pendidik harus memiliki kualifikasi akademik dan kompetensi sebagai agen pembelajaran, sehat jasmani dan rohani, serta memiliki kemampuan untuk mewujudkan tujuan pendidikan nasional. Dan pada ayat (2) dijelaskan, bahwa kualifikasi akademik sebagaimana dimaksud pada ayat (1) adalah tingkat pendidikan minimal yang harus dipenuhi oleh seorang pendidik yang dibuktikan dengan ijazah dan/atau sertifikat keahlian yang relevan sesuai ketentuan perundang-undangan yang berlaku. Berikutnya pada ayat (3) dipertegas, bahwa kompetensi sebagai agen pembelajaran

2Abdurahman Wahid. 1984. "Pesantren sebagai Subkultur", dalam M. Dawam Rahardjo. Pesantren. Jakarta: LP3ES, hh. 43-46. 
pada jenjang pendidikan dasar dan menengah serta pendidikan anak usia dini meliputi: a. kompetensi pedagogik; b. kompetensi kepribadian; c. kompetensi profesional; dan d. kompetensi sosial. Selanjutnya pada ayat (4) dinyatakan, bahwa seseorang yang tidak memiliki ijazah dan/ atau sertifikat keahlian sebagaimana dimaksud pada ayat (2) tetapi memiliki keahlian khusus yang diakui dan diperlukan dapat diangkat menjadi pendidik setelah melewati uji kelayakan dan kesetaraan.

Sehubungan dengan itu, dalam Undang-Undang RI Nomor 20 Tahun 2003 tentang Sistem Pendidikan Nasioanl pada Bab XI Pasal 39 ayat (2) menyebutkan, bahwa pendidik merupakan tenaga professional yang bertugas merencanakan dan melaksanakan proses pembelajaran, menilai hasil pembelajaran, melakukan pembimbingan dan pelatihan. Dan dalam Peraturan Pemerintah RI Nomor 74 Tahun 2008 tentang Guru pada Bab I Pasal 1 ayat (1) disebutkan bahwa yang dimaksud guru adalah pendidik profesional dengan tugas utama mendidik, mengajar, membimbing, mengarahkan, melatih, menilai, dan mengevaluasi peserta didik pada pendidikan anak usia dini jalur pendidikan formal, pendidikan dasar dan pendidikan menengah.

Masalah penelitian yang ingin dijawab adalah bagaimana pengadaan, penempatan, dan pengembangan pendidik di pondok pesantren ? Untuk itu, secara umum penelitian ini bertujuan untuk mengetahui pola pembinaan pendidik di pondok pesantren. Sedangkan secara khusus penelitian ini bertujuan untuk mengetahui pengadaan, penempatan, dan pengembangan pendidik di pondok pesantren.

Hasil penelitian ini diharapkan bermanfaat sebagai bahan masukan dalam menyusun dan menetapkan kebijakan pembinaan pondok pesantren oleh Ditjen Pendidikan Islam Direktorat Pendidikan Diniyah dan Pondok Pesantren, Kanwil Departemen Agama serta unit-unit dan pihak-pihak terkait dalam pembinaan pondok pesantren dan untuk pondok pesantren itu sendiri.

Penelitian ini dilaksanakan di Pondok Pesantren Nurul Hakim Kediri Lombok Barat NTB, Jenis penelitian ini adalah deskriptif dan metode yang digunakan dalam penelitian ini adalah metode kualitatif.

Informan penelitian adalah komunitas pondok pesantren yang terdiri dari: pengurus yayasan, pimpinan/pengasuh pondok pesantren, tuan guru, kepala, guru/ustadz dan kepala tata usaha MI, MTs, MA dan Ma'had Aly. 
Instrumen dan pengumpulan data dilakukan dengan teknik, sebagai berikut: a) studi kepustakaan dan dokumnen; b) wawancara mendalam; c) kuesioner;

\section{TEMUAN DAN PEMBAHASAN}

\section{A. Pengadaan Pendidik}

Berdasarkan data asatidz dan karyawan Pondok Pesantren Nurul Hakim tahun 2006, baik asatidz dan karyawan yang bertugas pada lembaga pendidikan formal maupun nonformal dari jenjang pendidikan anak usia dini, pendidikan dasar, pendidikan menengah sampai pendidikan tinggi berjumlah 247 orang.

Asatidz/guru MI, MTs dan MA Pondok Pesantren Nurul Hakim semuanya (100\%) adalah sarjana (S-1), bahkan terdapat beberapa ustadz/guru yang berpendidikan Strata 2 (S-2), juga sebagian besar $(83,02 \%)$ dari Fakultas dan jurusan keguruan.

Jika jumlah guru/ustadz dilihat dari latar belakang pendidikan pondok pesantren dan bukan alumni dari pondok pesantren, maka terdapat sebagian besar, yaitu 49 orang $(92,45 \%)$ adalah alumni pondok pesantren (pernah belajar di pondok pesantren). Hanya sebagian kecil tenaga pendidik $(7,55 \%)$ yang tidak berasal dari pondok pesantren.

Dilihat dari segi masa kerja, maka dapat diketahui bahwa guru/ ustadz yang memiliki masa kerja relatif baru, yaitu masa kerja 0 sampai 4 tahun, hanya sebagian kecil, yaitu 15 guru/ustadz (28,30 \%). Artinya, guru/ustadz MI, MTs dan MA Pondok Pesantren Nurul Hakim sebagian besar, yaitu 38 orang $(71,70 \%)$ telah memiliki masa kerja (pengalaman) yang memadai, yaitu telah memiliki pengalaman mengajar selama 5 tahun lebih.

Melalui wawancara dengan Pengasuh/Pimpinan Pondok Pesantren Nurul Hakim almukarram Tgh. Shofwan Hakim dan beberapa tuan guru, antara lain; Tgh. Muzakkar Idris, Lc, M.Si ${ }^{3}$, diperoleh informasi bahwa pengadaan pendidik(ustadz/guru) di pondok pesantren ini, sangat jauh berbeda dengan pengadaan guru di sekolah umum, bahkan di madrasah di luar pondok pesantren. Sebab pada hakekatnya semua jenis dan jenjang pendidikan yang berlangsung di lingkungan pondok

\footnotetext{
${ }^{3}$ Wawancara dilakukan pada tgl. 18 Juli 2008.
} 
pesantren ini membawa misi untuk pembentukan mental spritual dan akhlaqul karimah (liutammima makarimab akblaq).

Dengan demikian, model/pola pengadaan (rukrutmen) pendidik (guru/ustadz) di pondok pesantren Nurul Hakim ini dilakukan dengan melalui model/pola, sebagai berikut:

1. Model/Pola Kaderisasi

Pondok Pesanten Nurul Hakim sejak dari awal telah mempersiapkan para pendidik (guru/asatidz) dengan pola kaderisasi, baik guru yang akan ditugaskan pada jenjang pendidikan anak usia dini, pendidikan dasar, pendidikan menengah maupun pada jenjang perguruan tinggi, yaitu dengan cara santri/wati yang berprestasi tinggi (sangat memuaskan) diberikan beasiswa oleh pondok pesantren ini untuk melanjutkan studinya, baik ke luar negeri maupun dalam negeri.

\section{Model/Pola Seleksi}

Selama ini pihak Pondok Pesanten Nurul Hakim tidak pernah membuat pengumumuan penerimaan calon pendidik (guru/ustadz/ ah) dan tenaga kependidikan. Meskipun demikian, ternyata cukup banyak calon pendidik dan tenaga kependidikan yang menyampaikan lamarannya ke pondok pesantren ini. Dalam hal ini, sebagian besar mereka yang menyampaikan surat lamaran adalah mereka yang baru lulus dari perguruan tinggi (sarajan/S-1) yang belum memiliki pekerjaan tetap. Bagi mereka yang telah memiliki pekerjaan tetap, hanya sebagian kecil yang menyampaikan surat lamaran.

Menurut ustadz Ma'mun, S.Pd, ${ }^{4}$ ia mengajukan surat lamaran ke Pimpinan/pengasuh Pondok Peantren Nurul Hakim untuk mengajar Bahasa Inggris, sekitar setahun setelah mengajukan surat lamaran, baru beliau mendapat panggilan untuk mengikuti tes seleksi (tes wawancara).

\section{B.Penempatan Pendidik}

Dalam wawancara dengan Pengasuh/Pimpinan Pondok Pesantren Nurul Hakim almukarram Tgh. Shofwan Hakim dan beberapa tuan guru, antara lain; Tgh. Muzakkar Idris, Lc, M.Si, Ustadz H. Moh. Fahrizal, S.Pd.I ${ }^{5}$, beliau menyatakan, bahwa dalam penempatan pendidik

\footnotetext{
${ }^{4}$ Wawancara dilakukan pada tgl. 16 Juli 2008.
}

${ }^{5}$ Wawancara dilakukan pada tgl. 19 Juli 2008. 
harus berpegang teguh kepada prinsip, yaitu bahwa tugas guru selain memiliki tugas utama untuk mendidik, mengajar, membimbing, mengarahkan, melatih, menilai, dan mengevaluasi peserta didik/santri. Juga, pendidik tersebut harus mampu menjadi suri tauladan, baik bagi santri, sesama guru dan tenaga kependidikan lainnya maupun bagi masyarakat luas.

Menurut Pengasuh/Pimpinan Pondok Pesantren Nurul Hakim almukarram 'Tgh. Shofwan Hakim, Tgh. Muzakkar Idris, Lc, M.Si dan Ustadz H. Moh. Fahrizal, S.Pd.I, pesantren sangat memprioritaskan kesesuaian latar belakang pendidikan dengan bidang studi yang diampuh (diajarkan). Sampai saat ini penerimaan dan penempatan pendidik di pondok pesantren ini sebagian besar ( $95 \%$ ) telah sesuai dengan latar belakang pendidikan dengan bidang studi yang diampuh (diajarkan).

\section{Pengembangan Pendidik}

Melalui wawancara dengan Pengasuh/Pimpinan Pondok Pesantren Nurul Hakim almukarram Tgh. Shofwan Hakim dan beberapa tuan guru, antara lain; Tgh. Muzakkar Idris, Lc, M.Si, Ustadz H. Moh. Fahrizal, S.Pd.I ${ }^{6}$ dapat diketahui, bahwa semua (100\%) pendidik, bahkan tenaga kependidikan di pondok pesantren ini telah mengikuti pendidikan dan pelatihan, baik yang diselenggarakan oleh Departemen Agama, Dinas Pendidikan, Lembaga Pengembangan Mutu Pendidikan, maupun yang diselenggarakan oleh pondok pesantren kerjasama dengan Pemerintah Daerah ${ }^{7}$

Di samping itu, di Pondok Pesantren Nurul Hakim secara rutin, yaitu sekali sebulan diadakan pertemuan (silaturrabim) antara pengurus yayasan, pimpinan/pengasuh pondok pesantren dengan para guru. Dalam pertemuan (silaturrabim) tersebut, selain dimaksudkan untuk mempererat hubungan kekerabatan dan kekeluargaan warga pondok pesantren.

Hubungan kekerabatan dan kekeluargaan yang telah berjalan di pondok pesantren ini, tidak hanya berjalan harmonis dalam warga di lingkungan pesantren. Tapi, juga dapat berjalan secara harmonis dengan

${ }^{6}$ Wawáncara dilakukan pada tgl. 19 Juli 2008.

7 Wawancara dilakukan pada tgl. 18 Juli 2008. 
para alumni pondok pesantren. Selama ini hubungan kekerabatan dan kekeluargaan dengan para alumni telah terjalin dengan harmonis melalui Ikatan Alumni Pondok Pesantren Nurul Hakim (IKAPPNH) yang dipimpin langsung oleh ketua yayasan pondok pesantren ini.

Selanjutnya Pengasuh/Pimpinan Pondok Pesantren Nurul Hakim almukarram Tgh. Shofwan Hakim dan beberapa tuan guru, antara lain; Tgh. Muzakkar Idris, Lc, M.Si, Ustadz H. Moh. Fahrizal, S.Pd.I ${ }^{8}$ dalam wawancara mengungkapkan, bahwa "Daftar Penilaian Pelaksanaan Pekerjaan (DP3)" bagi pendidik dan tenaga pendidikan di pesantren ini secara resmi (secara tertulis) sebagaimana halnya pada Pegawai Negeri Sipil sampai saat ini tidak ada. Karena penilaian semacam itu, baik menurut ketua yayasan maupun pimpinan/pengasuh pondok pesantren menganggapnya tidak perlu untuk diterapkan, baik terhadap tenaga pendidik maupun terhadap tenaga kependidikan. Sebab, menurut ketua yayasan dan pimpinan/pengasuh pondok pesantren ini penilaian melalui DP3 tersebut lebih cenderung hanya bersifat formalitas dan rutinitas belaka.

Adapun mengenai proses promosi jabatan bagi pendidik, misalnya; diangkat sebagai Kepala Madrasah Ibtidaiyah, Kepala Madrasah Tsanawiyah, Kepala Madrasah Aliyah atau jabatan lainnya, menurut ketua yayasan dan pimpinan pesantren ini berdasarkan berbagai aspek, antara lain; berdasarkan kepada sejauhmana sikap dan perilaku mereka dapat dijadikan ketauladan (uswatun hasanab) dalam kehidupan seharihari baik oleh santri maupun masyarakat luas, latar belakang pendidikan, masa pengabdian, prestasi kerja, loyalitas terhadap pondok pesantren.

Lebih lanjut Pimpinan Pondok Pesantren Nurul Hakim almukarram Tgh. Shofwan Hakim menyatakan, bahwa di pondok pesantren ini tidak ada standar atau kriteria untuk mempesiunkan pendidik. Dalam hal ini, selama guru/ustadz masih dalam keadaan sehat wal afi'at dan mampu menjalankan tugas sebagai pendidik, maka selama itu pula tidak pensiun.

${ }^{8}$ Wawancara dilakukan pada tgl. 19 Juli 2008. 


\section{PENUTUP}

\section{A. Kesimpulan}

1. Pondok Pesantren Nurul Hakim telah berhasil dalam pengadaan pendidik melalui model/pola kaderisasi dan seleksi.

2. Penempatan pendidik di pesantren ini sebagian besar telah memenuhi kualifikasi akademik dan sesuai latar belakang pendidikan dengan bidang studi yang diampuhnya.

3. Dalam pengembangan pendidik, pimpinan Pondok Pesantren Nurul Hakim tidak hanya berupaya untuk mengikutsertakan guru-guru dalam berbagai pendidikan dan pelatihan. Tapi, juga memberi kesempatan (mengizinkan) kepada guru-guru untuk melanjutkan studinya baik dalam negeri maupun luar negeri dengan biaya sendiri maupun beasiswa.

\section{B. Rekomendasi}

1. Sebaiknya Direktorat Pendidikan Diniyah dan Pondok Pesantren Departemen Agama dapat membina pendidik yang mampu melakukan pembinaan yang mengarahkan pesantren, agar menjadi partner yang ideal bagi instansi pemerintah yang ada di daerah sebagai basis pelaksanaan transformasi sosial melalui penyediaan sumberdaya manusia yang qualified dan berakhlaqul karimah.

2. Sebaiknya Direktorat Pendidikan Diniyah dan Pondok Pesantren Departemen Agama dalam melakukan pembinaan pendidik yang memiliki profesionalisme untuk mengarahkan dan pengembangan pendidikan pondok pesantren untuk memperkuat karakter sosial sistem pendidikan nasional yang turut membantu melahirkan sumberdaya manusia yang memiliki kehandalan pengetahuan dan kecakapan teknologi yang senantiasa dijiwai nilai-nilai luhur keagamaan.

3. Hendaknya pimpinan pesantren dalam melakukan pembinan pendidik yang mampu memperluas (diversifikasi) komunitas pembelajaran dengan memasukkan berbagai macam sektor pendidikan (umum, keterampilan profesional), tetap berpegang teguh kepada prinsip 
untuk menjaga, mempertahankan dan mengembangkan pendidikan keagamaan (mutafaqqib fiddin).

\section{SUMBER BACAAN}

Bungin, Burhan (2004): Metodelogi Penelitian Kualitatif. Jakarta, Raja Grafindo Persada.

Departemen Agama RI (2005/2006): Statistik Pendidikan Agama dan Keagamaan, Jakarta, Ditjen Pendis.

Dhofier, Zamakhsyari (1982): Tradisi Pesantren: Studi Tentang Pandangan Hidup Kyci. Jakarta, LP3ES.

Hamidi (2004): Metode Penelitian Kunlitatif. Malang, Universitas Muhammadiyah Malang.

Mastuhu (1994): Dinamika Sistem Pendidikan Pesantren. Jakarta, INIS.

Pondok Pesantren Nurul Hakim (2008): Sejarah Pondok Pesantren Nurul Hakim, Data tentang: Lembaga Pendidikan, Lembaga Sosial, Jumlab Santri/Siswa, Tuan Guru/Ustady/ah, Sarana-Prasarana dan Profil Pondok Pesantren Nurul Hakim. Kediri, Lombok Barat Nusa Tenggara Barat.

Peraturan Pemerintah RI Nomor 55 Tahun 2007: Tentang Pendidikan Agama dan Pendidikan Keagamoan.

Peraturan Pemerintah RI Nomor 74 Tahun 2008: Tentang Guri

Rahardjo, Dawam, Ed. (1974): Pesantren dan Perubahan, Jakarta, LP3S.

Steenbrink, Karel A (1986): Pesantren, Madrasab, Sekolab: Pendidikan Islam Dalam Kurun Modern, Jakarta. LP3ES.

Sukmadinata, Nana Syaodah (2005): Metode Penelition Kualitatif. Bandung, Remaja Rosdakarya.

Sugiyono (2006): Metode Penelitian Kuantitatif - Kralitatif dan R \& D. Bandung, Alfabeta.

Undang-Undang RI Nomor 14 Tahun 2005 (2005): Tentang Guru dan Dosen, Yogyakarta, Aditya Pustaka.

Undang-Undang RI Nomor 20 Tahun 2003 (2003): Tentang Sistem Pendidikan Naizonal. Jakarta, Mitra Karya.

Wahid, Abdurrahman (1974): "Pesantren Sebagai Subkultur" dalam M. Dawam Rahardjo, Pesantren dan Pembaharuan. Jakarta, LP3ES.

Wahjosumidjo (2001): Kepemimpinan Kepala sekolab Tinjonan Teori dan Permasialabannya. Jakarta, Raja Grafindo Persada. 